\title{
Characteristics of Patients with Obstetric and Gynecologic Fistula in Jakarta
}

\section{Karakteristik Pasien dengan Fistula Obstetri dan Ginekologi di Jakarta}

\author{
Suskhan Djusad, Ambalagen Sonia, Anthonyus Natanael \\ Department of Obstetrics and Gynecology \\ Faculty of Medicine Universitas Indonesia/ \\ Dr. Cipto Mangunkusumo Hospital \\ Jakarta
}

\begin{abstract}
Objective: To know the characteristics of patients with obstetrics and gynecologic fistula in Dr. Cipto Mangunkusumo Hospital, Jakarta.

Method: This study was a descriptive design using secondary data from medical records and patient database during 2011-2016.

Result: There were 68 subjects with fistula. From 2011-2016, there were 5 cases $(7.4 \%), 19$ cases $(27.9 \%), 16$ cases $(23.5 \%), 11$ cases $(16.2 \%), 8$ cases $(11.8 \%)$, and 9 cases $(13.2 \%)$ of fistula; respectively. The average age of subjects was 38 years old and only 34 subjects have complete data. Gynecologic and obstetric fistula were 17 cases each. As total $28 \%$ of fistula cases were vesicovagina fistula, $12 \%$ were rectovaginal fistula, 9\% were anovagina fistula, and the other types of fistula were $2 \%$. Among 34 subjects, there were $21 \%$ of vesicovagina fistula and $3 \%$ of rectovagina fistula, which were caused by iatrogenic. There were $7 \%$ of vesicovagina and rectovagina fistula each and $9 \%$ of anovagina fistula were caused by obstetric problems. The iatrogenic procedures found from this study were total abdominal hysterectomy $(16 \%)$, vaginal hysterectomy (3\%), and neovagina (3\%).

Conclusion: The trend of cases is decreasing during the present years (2011-2016). Gynecologic fistula cases caused by iatrogenic are the major problems, but the obstetrics fistula cases decreasing following the labor monitoring is much better nowadays.

[Indones J Obstet Gynecol 2016; 4-4: 212-217]
\end{abstract}

Keywords: gynecologic fistula, iatrogenic, obstetric fistula

\section{Abstrak}

Tujuan: Diketahuinya karakteristikpasien dengan fistula obstetri dan ginekologi di RSCM, Jakarta.

Metode: Studi ini merupakan studi deskriptif dengan menggunakan data sekunder dari rekam medis dan data rekapitulasi pada tahun 2011-2016.

Hasil: Terdapat total 68 subjek yang didiagnosis dengan fistula. Dari tahun 2011 - 2016, terdapat 5 kasus (7,4\%), 19 kasus (27,9\%), 16 kasus (23,5\%), 11 kasus (16,2\%), 8 kasus $(11,8 \%)$, dan 9 kasus $(13,2 \%)$, berurutan. Usia rata-rata subjek adalah 38 tahun dan hanya 34 subjek yang memiliki data yang lengkap. Fistula ginekologi dan obstetri masing-masing sebanyak 17 kasus. Fistula vesikovagina sebanyak 28\%, fistula rektovagina sebanyak $12 \%$, fistula anovagina sebanyak 9\%, dan fistula tipe lain sebanyak 2\%. Dari 34 subjek, didapatkan fistula vesikovagina (21\%) dan rektovagina (3\%) yang disebabkan oleh tindakan iatrogenik. Fistula vesikovagina dan rektovagina masing-masing sebanyak (7\%) dan anovagina (3\%) disebabkan oleh masalah obstetri. Tindakan iatrogenik yang didapat pada studi ini adalah histerektomi total abdominal (16\%), histerektomi transvaginal (3\%), dan neovagina (3\%).

Kesimpulan: Tren jumlah kasus menurun pada saat tahun 2011 2016. Fistula ginekologi yang disebabkan oleh tindakan iatrogenik merupakan masalah utama saat ini dibandingkan dengan jumlah kasus fistula obstetri yang menurun seiring pemantauan persalinan yang lebih baik.

[Maj Obstet Ginekol Indones 2016; 4-4: 212-217]

Kata kunci: fistula ginekologi, fistula obstetri, iatrogenik

Correspondence: A. Sonia, sonia_priyadarshini91@yahoo.com

\section{INTRODUCTION}

In developing countries, fistula is the conseqence of poor perinatal care. Fistula can be found per 1,000 labors and the prevalence of fistula is around $0.1 \%$ to $1.5 \%$ per 1000 pregnancies. The major risk factors are early marriage, short stature, poor antenatal care, low socio-economic status, low educational level, and family income or occupation. ${ }^{1}$ However, the main factor causing obstetric fistula is obstructed labor. Female who gets fistula will affect their psychosocial status. The psychosocial condition, as mentioned, are divorces (16-92\%), socially isolated, the deterioration of poverty, mal- nutrition, sexual dysfunction, and the disturbance of mental health (anxiety and depression), insomnia, and attempt of suicides. ${ }^{1}$

A study conducted by Waaldjik in Africa showed that the incidence of fistula was 1-2 cases per 1,000 deliveries. The number of incidence represented 50,000-100,000 new cases and the prevalence of fistula could reach 2 million of cases in the world nowadays. In Zambia, there were 259 cases of obstetric fistula, but there were only $95.5 \%$ cases of obstetric fistula reported as the consequences of prolonged labor (more than 24 hours). In Ethiopia, around $92 \%$ cases of obstetric fistula were related 
to poor antenatal care. In Nigeria, there were $85 \%$ cases of fistula caused by labored at home. ${ }^{1}$

Based on a study, there were $8.9 \%$ to $86 \%$ patients with obstetric fistula who were found mostly in teenagers. Besides, around $31 \%$ to $66.7 \%$ of cases were found in primiparous women. The mean time of labor which increased the risk of fistula was from 2.5 to 4 days. About $20 \%$ to $95.7 \%$ of women getting the obstetric fistula had prolonged labor (more than 24 hours). ${ }^{2}$

In developing countries, as well as industrial countries, the prevalence of gynecologic fistula is still lowered as compared with obstetric fistula. ${ }^{1}$ In developing countries, there are more than $90 \%$ of urogenital fistula caused by pelvic surgery. The involvement of urinary tracts is around $1 \%$ of gynecologic surgery and caesarean section. ${ }^{3}$ There-fore, this study aims to know the characteristics of patients with obstetric and gynecologic fistula in Dr. Cipto Mangunkusumo Hospital.

\section{METHODS}

This was a descriptive study design. We recruited samples from secondary data of medical records and patient databases in Division of Urogynecology, Department of Obstetrics and Gynecology, Faculty of Medicine Universitas Indonesia, Dr. Cipto Mangunkusumo Hospital, between 2011 and 2016. The inclusion criteria were women diag-nosed with fistula during the period of time. The types of fistula were categorized into obstetric and gynecologic fistula. Each of them would be divided into vesicovagina, rectovagina, anovagina, and the other types of fistula. In the age category, it would be divided into 3 groups, such as under 20 years old, 20-35 years old, and above 35 years old.

Perineal laceration would be classified into 2 groups, as mild and severe degree of laceration. Mild degree was defined as first and second degree of perineal laceration. Severe laceration was defined as more than second degree of perineal laceration.

The heaviest birth weight of newborn would be categorized into 3 groups, namely less than 2,500 grams (small), 2,500-4,000 grams (normal), and more than 4,000 grams (large). The risk factor of obstetric fistula would be seen from the procedure and the problem found in this study. It was similar definition for the gynecologic fistula. In this study, all data were processed using SPPS program version 23.0 .

\section{RESULTS}

The data was obtained during the last 5 years and the results were 68 subjects who were diagnosed with fistula. of 68 subjects, there were $28 \%$ patients of vesicovagina fistula, $11 \%$ patients of rectovagina fistula, $9 \%$ patients of anovagina fistula, and $2 \%$ patients with other types of fistula (urethrovagina, vesicocervicovagina, vesicorectovagina). These number were the summary of both obstetric and gynecologic fistula. The average age of the subjects was 38 years old.

In this study, there were 3 subjects under 20 years old, 29 subjects who were 20 to 35 years old, and 36 subjects who were above 35 years old. Meanwhile, the distribution of nulliparous, primiparous, and multiparous women were 4,13 , and 15 subjects; contributively.

The cases of obstetric fistula had several risk factors including the heaviest birth weight and the degree of obstetrical anal sphincter injuries (OASIS). In this study, there were only 1 subject with history of having labor less than 2,500 grams, 19 subjects of 2,500-4,000 grams, and 3 subjects of above 4,000 grams. Based on the degree of perineal laceration, there were no subjects who had mild degree of perineal laceration $\left(1^{\text {st }}\right.$ degree and $2^{\text {nd }}$ degree of perineal rupture); however, there were 12 subjects who had severe perineal laceration $\left(>2^{\text {nd }}\right.$ degree $)$.

Based on the types of fistula, there were vesicovagina, rectovagina fistula, anovagina, and other types including urethrovagina, vesicocervicovagina, and vesicorectovagina fistula. Among 68 sub-

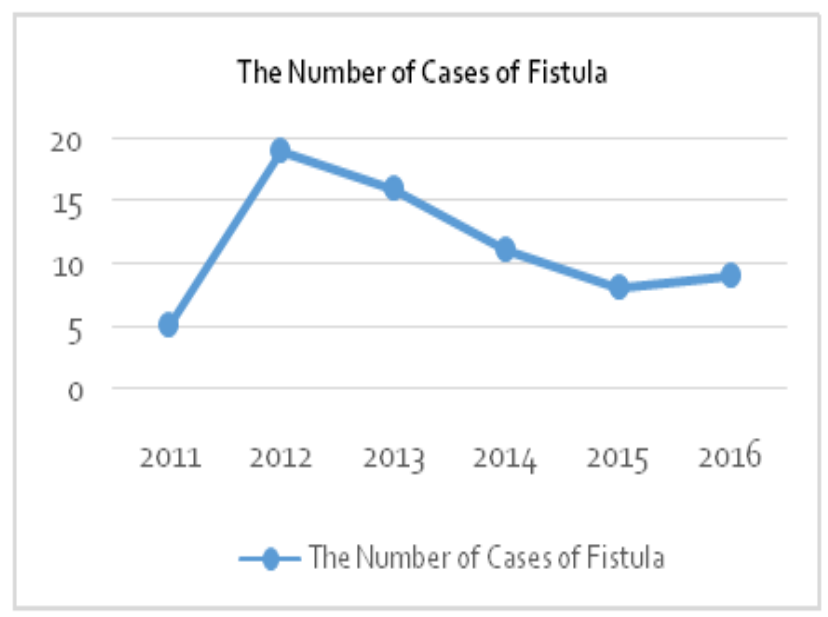

Figure 1. The Trend of Fistula Cases during 2011-2016 in Dr. Cipto Mangunkusumo Hospital. 
jects, there were 35 subjects diagnosed as vesicovagina fistula, 17 subjects as rectovaginal fistula, 10 subjects as anovagina fistula, and 6 subjects as other types of fistula.

Fistula is classified as two types, such as obstetric and gynecologic fistula. Obstetric fistula is a fistula caused by obstetric related problems, such as prolonged second stage of labor, perineal laceration, obstetric procedure (caesarean section and assisted vaginal delivery). In this study, among 34 subjects with complete medical records, there were 17 subjects of each case group. From 2011 to 2016 , there were $5(7.4 \%), 19(27.9 \%)$, $16(23.5 \%), 11(16.2 \%), 8(11.8 \%)$, and 9 cases; respectively. Actually, the cases in 2006 were less than other years due to the number of months from samples taken, namely between January and March.

Table 1. The Characteristics of Obstetric and Gynecologic Fistula in Dr. Cipto Mangunkusumo Hospital during 2011 to 2016

\begin{tabular}{|c|c|c|}
\hline \multirow{2}{*}{ Variables } & \multicolumn{2}{|c|}{$\mathrm{N}=68(\%)$} \\
\hline & $\begin{array}{c}\text { Obstetric fistula } \\
\text { n (\%) }\end{array}$ & $\begin{array}{c}\text { Gynecologic fistula } \\
\text { n (\%) }\end{array}$ \\
\hline \multicolumn{3}{|l|}{ Age } \\
\hline$<20$ years old & $1(2)$ & $0(0)$ \\
\hline 20 - 35 years old & $13(19)$ & $3(4)$ \\
\hline$>35$ years old & $3(4)$ & $14(21)$ \\
\hline $\mathrm{N} / \mathrm{A}$ & \multicolumn{2}{|c|}{$34(50)$} \\
\hline \multicolumn{3}{|l|}{ The types of fistula } \\
\hline Vesicovagina & $5(7)$ & $14(21)$ \\
\hline Rectovagina & $5(7)$ & $3(4)$ \\
\hline Anovagina & $6(9)$ & $0(0)$ \\
\hline Others & $1(2)$ & $0(0)$ \\
\hline $\mathrm{N} / \mathrm{A}$ & \multicolumn{2}{|c|}{$34(50)$} \\
\hline \multicolumn{3}{|l|}{ Risk Factors } \\
\hline \multicolumn{3}{|l|}{ For obstetric } \\
\hline Caesarean section & $3(4)$ & \\
\hline Prolonged second stage of labor & $1(2)$ & \\
\hline Assissted/operative vaginal delivery & $2(3)$ & \\
\hline \multicolumn{3}{|l|}{ Perineal laceration } \\
\hline Mild & $0(0)$ & \\
\hline Severe & $12(18)$ & \\
\hline \multicolumn{3}{|l|}{ The heaviest birth weight of newborn } \\
\hline Small $(<2500$ grams $)$ & $1(2)$ & \\
\hline Normal (2500-4000 grams) & $13(19)$ & \\
\hline Large (> 4000 grams) & $3(4)$ & \\
\hline \multicolumn{3}{|l|}{ Gynecologic procedures/abnormalities } \\
\hline Transvaginal hysterectomy (TVH) & & $2(3)$ \\
\hline Total abdomninal hysterectomy (TAH) & & $11(16)$ \\
\hline Neovagina & & $2(3)$ \\
\hline Pelvic organ prolapse & & $2(3)$ \\
\hline Sexual abused & & $0(0)$ \\
\hline $\mathrm{N} / \mathrm{A}$ & & \\
\hline
\end{tabular}


Among the subjects who had obstetric fistula mostly were in the range of 20 years old until 35 years old. However, there was one subject who had obstetric fistula in the age of under 20 years old. The type of fistula mostly was anovagina fistula, which were found around 6 cases. Meanwhile, vesicovagina and rectovagina fistula were as many as the other types of fistula namely 5 cases.

One of risk factors is obstructed labor. In this study, there was one subject who had obstetric fistula because of prolonged second stage of labor. In addition, assisted vaginal delivery including forceps and vacuum, influenced the fistula formation. This study reported that there were 2 subjects who had obstetric fistula with a previous history of assisted vaginal delivery.

There were 12 subjects with the previous history of severe perineal laceration. In this study, subjects who had severe perineal laceration, mostly had anovagina and rectovagina fistula.

Based on the heaviest birth weight, this study showed that the most cases were found among the subjects having history of delivering 2,500 to 4,000 grams. Nevertheless, birth weight more than 4000 grams affected the fistula formation showed by 3 cases in this study.

Most of the gynecologic fistula cases were found in the age of above 35 years old. Vesicovagina fistula was the most often types of fistula in this study. Gynecologic fistula was mostly affected by gynecologic procedure or iatrogenic. In this study, we found several gynecologic procedures, such as transvaginal hysterectomy, transabdominal hysterectomy, and artificial vagina procedure or neovagina. There were 2 cases due to transvaginal hysterectomy, 11 cases due to transabdominal hysterectomy, and 2 cases because of artificial vagina procedures. There were some gynecologic abnormalities found in this study. They were uterine prolapse and cystorectocele. This study found 2 subjects who had those gynecologic abnormalities. Sexual abuse could be one of the risk factors or the cause of gynecologic fistula called as traumatic gynecologic fistula. However, this study did not find any subjects with the history of sexual abuse.

\section{DISCUSSION}

In this study, the average age of the subjects was 38 years old which the most subjects were in the range of 20-35 years old. This corresponded to a study conducted by Kazaura, et al., they stated that there were 334 subjects who had obstetric fistula, $72.2 \%$ among them were in the range of $25-29$ years old. ${ }^{4}$ One meta-analysis study conducted by Ahmed, et al. showed that almost $80 \%$ of women had chronic excoriation due to direct irritation by urine. $^{4}$

Fistula tended to interfere women's social and psychosexual life. In a study conducted by Okoyei, et al., women who had fistula had been in emotional instability. ${ }^{4}$ However, in this study, we did not do assessment of psychosexual aspects among the subjects.

Especially, obstetric fistula is caused by obstructed labor which happened during full bladder. ${ }^{5}$ Early marriage is one of the significant risk factors for the obstetric fistula. Delayed to get married and pregnant will reduce the complications of labor.

In this study, there were 17 cases of obstetric fistula, caused by prolonged second stage of labor and assissted vaginal delivery (forceps or vacuum). There were several primary risk factors, such as the duration of labor, the facilities and the health workers, partograph, poor antenatal care, early marriage, and aging population. A study conducted by Unfer, et al. showed that there was higher incidence of obstetric fistula among women delivering low birth weight baby, especially in teenage population. The increasing obstetric risk in teenage is due to immaturity of anatomical structure on pelvic organ and bone. ${ }^{2}$

The teenage pregnancy has the highest prevalence in developing countries (7-30\%) and it is associated with the incidence of cephalopelvic disproportion. ${ }^{6}$ One of the strategies to reduce obstetric fistula is through prevention of teenage pregnancy. Women who have height under $155 \mathrm{~cm}$ and the age under 19 years old have 4.9 times higher risk in caesarean section. ${ }^{6}$ Regardless, caesarean section will increase the maternal and fetal outcomes in obstructed labor. ${ }^{6}$

The obstructed labor has been the major cause of maternal morbidity, such as infection and obstetric fistula. The obstructed labor is a mechanical process affected by the fetal size and malpresentation. According to World Health Organization (WHO), prolonged labor is defined as the labor taking place more than 18 hours. The formation of fistula is commonly found among primigravid patients. A case study conducted in Addis Ababa, 
Africa, there were $97 \%$ of vesicovagina fistula caused by obstructed labor, whereas $65 \%$ occurred among subjects in the age of under 25 years old, and $63 \%$ were primigravid. ${ }^{7}$ This was different from our study, which the proportion of fistula is commoner in multiparous than primiparous women. Vesicovagina fistula or obstetric fistula is caused by ischemic necrosis process of bladder tissue and vagina, which are trapped between the head of the fetus and the symphisis of maternal during the obstructed labor. Actually, it can impact to rectovagina fistula, in spite of very rarely condition. ${ }^{7}$ In case series conducted by Kano, in Sub-Saharan Africa, there were 120 subjects who had been diagnosed as vesicovagina fistula and most of them had early marriage. In Sokoto, same case series, there were $93.6 \%$ of the subjects having marriage before 18 years old. Obstetric fistula was mostly found in the age of 20 to 29 years old. Primiparous was the major group who had been diagnosed as vesicovagina fistula. ${ }^{8}$

The most common cause of non obstetric fistula or gyencologic fistula is iatrogenic procedure, such as pelvic surgery, trauma of the genital (coitus, sexual abused, accident, and genital mutilation), granulomatous infection, tuberculosis, and HIV. Not only those, but also there are congenital malformation, cancer especially cervical cancer with or without radiotherapy which influence to the occurrence of this fistula. ${ }^{9}$ In this study, among the 34 subjects, there were no subjects with the history of infection as well as cancer.

The gynecologic procedures in this study were total vaginal hysterectomy, total abdominal hysterectomy, and artificial vagina or neovagina. Abdominal hysterectomy surgery has the higher risk than vaginal hysterectomy in the formation of fistula. However, we did not find the incidence of fistula in supracervical hysterectomy. Meanwhile, gynecologic abnormalities of genital, such as uterine prolapse, were rarely found to be the cause of fistula. Nevertheless, if there are gynecologic abnormalities, they are usually associated with trauma, such as erosion caused by inserting pessary around vaginal wall near bladder. Iatrogenic urogenital fistula can be the result of pelvic surgery and radiotherapy which are associated with tissue damage. ${ }^{10}$

The most common type of iatrogenic fistula is vesicovagina fistula seen in our study. There were 14 cases out of 17 cases of vesicovagina fistula. A study reported that the prevalence of vesicovagina fistula caused by iatrogenic procedures was 60 to $75 \%$ by hysterectomy in non malignant cases, $30 \%$ by hysterectomy in malignant cases, and $6 \%$ by caesarean section. ${ }^{11}$ The risk of fistula formation of the pelvic organ associated with hysterectomy was $0.1 \%$ to $4 \%$. In a retrospective study in USA, they showed that gynecologic fistula caused by gynecologic procedure was $82 \%, 8 \%$ due to the obstetric procedure, and also $6 \%$ because of radiation. ${ }^{11}$ The incidence of genitourinary fistula caused by abdominal hysterectomy in non malignant cases was 1 from 1,000 cases. The degree of bladder injury is the main factor of the fistula formation. ${ }^{11}$ In a study, where there were 1,317 cases of hysterectomy in non malignant subjects, there were $46 \%$ abdominal hysterectomy, $48 \%$ vaginal hysterectomy, and $6 \%$ of them were performed by laparoscopy. All of them had become the risk factor of vesicovagina fistula followed by intraoperative injury of the bladder. ${ }^{11}$

Abdominal hysterectomy in non malignant cases was the second commonest cause $(21.6 \%)$ of gynecologic fistula, while vaginal hysterectomy, radical hysterectomy, and laparoscopic hysterectomy were $10.8 \%, 5.4 \%$, and $2.7 \%$, respectively. ${ }^{12}$ Laparoscopic hysterectomy has the highest incidence in bladder injury. However, in this study, abdominal hysterectomy has the largest proportion of cases than vaginal hysterectomy. In addition, there was one case of gynecologic fistula caused by hysterectomy followed by salphingectomy, as the underlying problem was ovarian cyst. This study also found that there were 3 cases of fistula with the previous history of caesarean section. Caesarean section has not been the direct cause of the fistula formation but the indication of this procedure should be considered. Indication of caesarean section could be due to fetal distress and obstructed labor itself which will be related to obstetric fistula. However, there are several caesarean section procedures which can be the main cause of the fistula formation because either there is prolonged and directed pressure on the bladder during the procedure or imperfect closing of the wound.

The strength of this study is the data which were obtained more than 5 years. Especially, this will be enough to represent the prevalence and incidence of fistula in Dr. Cipto Mangunkusumo Hospital. This study can be as the reference of the other studies. 
The limitation of this study is that there were some incomplete data regarding the subjects.

\section{CONCLUSION}

The number of fistula cases are similar among obstetric and gynecologic fistula during 5 years. The trend of these cases is decreasing concomitant to the improvement of technology and surgeon's skill. In this study, obstetric fistula cases are caused by prolonged second stage of labor, operative or assisted vaginal delivery, and severe degree of perineal laceration. Although, gynecologic fistula cases are mostly caused by hysterectomy or iatrogenic procedures and they still become the major problem nowadays. Nevertheless, obstetric fistula cases are decreasing in accordance with good labor monitoring.

\section{REFERENCES}

1. Abrams PCL, Khoury S, Wein A. Incontinence: ICAD EAU; 2013.

2. Tebeu PM, Fomulu JN, Khaddaj S, de Bernis L, Delvaux T, Rochat CH. Risk factors for obstetric fistula: a clinical review. Int Urogynecol J. 2012; 23(4): 387-94.
3. Goh J, Stanford EJ, Genadry R. Classification of female genito-urinary tract fistula: a comprehensive review. Int Urogynecol J Pelvic Floor Dysfunct. 2009; 20(5): 605-10.

4. Service GH. Report on the burden of obstetric fistula in Ghana. In: Service GH, editor. Ghana: Ghana Health Service; 2015.

5. Neilson J. Obstructed labour. Bri Med Bull. 2003; 67(1): 191-204.

6. Rochat CH. Obstetric fistula. Geneva: World Health Organization, Research MEa; 2014.

7. Kalembo FW, Zgambo M . Obstetric fistula a hidden public health problem In Sub-Saharan Africa. Arts Soc Scienc J. 2012: 9 .

8. Ijaiya AGR MA, Aboyeji AP, Olatinwo WO, Esuga SA, Ogah $\mathrm{OK}$, et al. Vesicovaginal fistula a review of Nigerian experience. West African J Med. 2010: 29.

9. Dangal G TK, Yangzom K, Karki A. Obstetric fistula in the developing world an agonising tragedy. NJOG. 2013; 8: 11.

10. Raassen TJ, Ngongo CJ, Mahendeka MM. Iatrogenic genitourinary fistula: an 18-year retrospective review of 805 injuries. Int Urogynecol J. 2014; 25(12): 1699-706.

11. Wall LL. Obstetric vesicovaginal fistula as an international public-health problem. The Lancet. 2006; 368(9542): 12019.

12. Singh OSSG, Mathur RJ .Urogenital fistula in women 5-year experience at a single center. Urol J. 2010; 7: 35-9. 